\title{
Special issue on "Management, governance and regulation in the changing investor landscape: the rise of alternative investments"
}

\author{
Igor Filatotchev $\cdot$ Mike Wright
}

Published online: 21 April 2013

(C) Springer Science+Business Media New York 2013

\section{Introduction}

In recent years, there has been a rapid growth in a large range of investment managers that represent alternatives to traditional equity holding in listed corporations by individuals and institutions such as pension funds and insurance. These alternative investors include private equity, hedge funds, sovereign wealth funds, infrastructure funds, etc. These trends have important implications for the management and governance of firms that have to date received varied attention. In particular, the changing investor landscape raises critical research questions regarding the structures and processes of shareholder engagement with portfolio companies. However, the extent to which alternative investors represent new forms of engagement and governance that cover all stages of firms' life-cycle is as yet unclear (Wright et al. 2013). The returns from some forms of alternative investors, notably private equity firms, have attracted other forms of entrants to the market such as hedge funds which may have different skills, different objectives and different investment time horizons. Similarly, the entry of sovereign wealth funds raises further issues and concerns about their strategic objectives and the implications for their portfolio companies.

The increase in the range and diversity of these investment institutions also raises direct questions about the extent to which the regulatory authorities are capable of dealing with the challenges that these new investment vehicles pose in terms of their involvement in corporate governance. Developments in the presence and roles of alternative investors have generated considerable policy debate and have led to

\footnotetext{
I. Filatotchev $(\bowtie)$

Cass Business School, City University London, London, UK

e-mail: Igor.Filatotchev.1@city.ac.uk
}

M. Wright

Imperial College Business School, London, UK 
actions to change the regulatory framework covering these organizations. The evidence base for these developments is partial at best and the appropriately differentiated regulatory approaches continue to attract attention.

The Centre for Research on Corporate Governance at Cass Business School, City University London jointly with the Journal of Management and Governance organized a conference in London in September 2011 that aimed to address these gaps in the evidence concerning the structures and processes through which governance and management are effected in firms with these new types of investors, and how these alternative investment firms are regulated. This Conference brought together academics, practitioners and regulators involved in research and policy development related to the changes in investor landscape in the UK and abroad. Apart from members of the research community, the audience included fund managers and their advisors, corporate governance practitioners and Government.

Academic papers presented at the Conference form the basis for this Special Issue and they cover a wide range of topics, research methodologies and empirical data. The paper by Muller-Kahle examines the impact of three types of dominant shareholders on firm performance. Using a longitudinal sample of firms in the US and UK, findings show that firm performance is negatively influenced by CEO dominant owners. Furthermore, firms with dominant owners who have no existing business relationships with the firms have better firm performance than firms with dominant owners who have potential conflicts of interest.

Faelten, Gietzmann and Vitkova develop a financial geography framework and analyze the impact of institutional information on the probability of a takeover being completed as well as on the post-takeover performance. Their research context is foreign M\&A and the role of changes in shareholding by institutional owners. It is hypothesised that regional expertise, that is, local knowledge, provides additional information to a potential acquirer. Therefore the key contribution of their paper is to test the relationship between low investor share turnover by institutions with local expertise and the probability of a deal occurring. It is also hypothesised that these deals will produce higher post merger returns.

Croci and Petrella exploit blockholders' legal filing requirements with the Italian regulatory authority (CONSOB) to examine trading and disclosure effects associated with hedge fund trades. Trading effects are related to hedge funds' buying activity on the market, whereas disclosure effects are related to the possibility that the market anticipates future activism and reacts to the announcement of hedge funds' ownership. The authors find that the trading effect is significantly larger than the disclosure effect. This result implies that the price impact associated with hedge fund purchases explains a large portion of the price reaction attributed exclusively to hedge fund activism in previous studies.

Weir, Jones and Wright are focused on the effects of private equity firms in public-to-private (PTP) transactions in the UK. Using a hand collected data set of 138 buy-outs, these authors show that for all PTPs there is a significant improvement in financial health in the post deal years relative to the year before going private. They also find that there is a significant improvement in the financial health of PTPs relative to firms remaining public. However, they suggest that the 
claims that the financial and governance mechanisms imposed by PE providers will produce better outcomes are strictly limited in the second wave of PTPs.

Finally, considering the recent rapid expansion of shareholder activism phenomenon in the United Kingdom (UK) and the vast amount of resources committed to it by corporations, government and investors, Filatotchev and Dotsenko investigate its effectiveness. This article analyzes organizational outcomes of shareholder activism in the UK. The authors provide a detailed account of different types of activists, activism strategies and shareholder demands associated with the events of activism. Their findings show that the effectiveness of shareholder activism in terms of abnormal stock-market returns varies dramatically depending on its form, type of investor and the nature of investor proposals.

It would be hard to provide a parsimonious account of a rapidly developing subfield of corporate governance research that is focused on the complex interaction between organizations and their investors, although the papers in this Special Issue address some important aspects of investor engagement and different types of investors. Other questions that future research might address include the following:

- How are board members selected in firms with alternative investors and what is their involvement in firm governance?

- How do the structures and processes of governance by alternative investors vary across different institutional contexts?

- How do the structures and processes of governance by alternative investors vary according to whether they are domestic or foreign investors in a particular country?

- How do different governance and management approaches of alternative investors pose challenges for the transition from one investor to another as firms pass through development phases?

- To what extent do different alternative investors encourage managers to pursue growth versus restructuring strategies?

- What are the time horizons of different alternative investors and how do these influence approaches to governance and management in portfolio companies?

We hope that researchers will be inspired by this Special Issue when addressing some of the aforementioned research questions.

\section{Reference}

Wright, M., Siegel, D., Keasey, K., \& Filatotchev, I. (2013). The Oxford handbook of corporate governance. Oxford: OUP.

\section{Author Biographies}

Igor Filatotchev is an Associate Dean for Research and Enterprise and Professor of Corporate Governance and Strategy at Cass Business School, City University London. He is also a Visiting Professor at Vienna University of Economics and Business (Austria). Before joining Cass he held various 
academic positions at Nottingham University Business School, Bradford University School of Management, King's College and Birkbeck College (University of London). He received his undergraduate degree in Mathematics from Moscow's Institute of Physics and Technology followed by a Ph.D. in Economics from the Institute of World Economy and International Relations (Moscow). His research examines corporate governance and strategic decisions, and current research programmes include analysis of resource and strategy roles of corporate governance; corporate governance life-cycle; and a knowledge-based view of governance development. He has published more than 100 articles in leading journals including Academy of Management Journal, Strategic Management Journal, Organization Science, Journal of Management and Journal of International Business Studies. He is an Associate Editor of Corporate Governance: An International Review and Journal of Management and Governance.

Mike Wright is Professor of Entrepreneurship at Imperial College Business School and Director of the Centre for Management Buyout Research. He is co-editor of Strategic Entrepreneurship Journal and Past Chair of the Academy of Management Entrepreneurship Division. He has published numerous papers and books on private equity and entrepreneurship in journals such as Academy of Management Journal, Academy of Management Review, Strategic Management Journal, Journal of Management Studies, Review of Economics and Statistics, etc. 